\title{
Development of sea ice microbial communities during autumn ice formation in the Ross Sea
}

\author{
David L. Garrison ${ }^{1,3, *}$, Martin O. Jeffries ${ }^{2}$, Angela Gibson ${ }^{3}$, Susan L. Coale ${ }^{3}$, \\ Diann Neenan ${ }^{3}$, Chris Fritsen ${ }^{4}$, Yuri B. Okolodkov ${ }^{5}$, Marcia M. Gowing ${ }^{3}$ \\ ${ }^{1}$ National Science Foundation, Division of Ocean Sciences, Biological Oceanography Program, Room 725, \\ 4201 Wilson Boulevard, Arlington, Virginia 22230, USA \\ ${ }^{2}$ Geophysical Institute, University of Alaska Fairbanks, Fairbanks, Alaska 99775-7320, USA \\ ${ }^{3}$ Institute of Marine Sciences, University of California Santa Cruz, Santa Cruz, California 95064, USA \\ ${ }^{4}$ Desert Research Institute, PO Box 60220, Reno, Nevada 89506, USA \\ ${ }^{5}$ Universidad Autonoma Metropolitana, Iztapalapa (UAM-I), Laboratorio de Fitoplancton Marino y Salobre, Departamento \\ de Hidrobiologia Division CBS, Avenida San Rafael Atlixco No. 186, Col. Vicentina, AP 55-525, 09340 Mexico, DF
}

\begin{abstract}
Sea ice communities were sampled across the Ross Sea in the austral autumn. The biota in first-year pack ice was assessed by measuring chlorophyll a (chl a), phaeopigments, total particulate carbon and nitrogen (POC and PON, respectively) and collecting samples for identification by microscopy. Physical and chemical parameters were also measured to characterize the environment. Chl a concentrations in ice ranged from 0 to $96.9 \mu \mathrm{g} \mathrm{l}^{-1}$ in discrete samples and from 0.02 to $20.9 \mathrm{mg} \mathrm{m}^{-2}$ for values integrated throughout floes. Maximum values were similar to those observed in first-year pack ice at other Antarctic locations. Chl a concentrations varied with ice structure and with latitude. POC:chl $a$ and $\mathrm{C}: \mathrm{N}$ ratios (molar) were high, possibly indicating detritus accumulations. The higher chl a levels north of approximately $72^{\circ} \mathrm{S}$ were apparently a result of ice forming in the south early in the season with subsequent advection to the north. These dynamics would result in older ice in the mid- or northern pack ice zone that was maintained in a favorable light and temperature regime during the seasonal progression of formation and drift. Chlorophyll levels were low in surface-layer communities. High chlorophyll concentrations were associated with internal communities. Bottom-layer algal populations, while present, did not reach the levels of high biomass reported for autumn blooms in some land-fast ice regions. Apparent nutrient and $\mathrm{CO}_{2}$ depletion were correlated with biomass parameters but accounted qualitatively for only a fraction of the biomass accumulation measured. Overall, autumn ice-associated production in the Ross Sea may be lower than expected because of the ice drift dynamics, apparently low production in the near-surface layers of first year ice flows, and the absence of rich bottom-layer assemblages.
\end{abstract}

KEY WORDS: Antarctic $\cdot$ Sea ice microbial communities $\cdot$ Chlorophyll a $\cdot$ POC $\cdot$ PON Resale or republication not permitted without written consent of the publisher

\section{INTRODUCTION}

Microbial communities have been observed throughout the land-fast and pack ice surrounding the Antarctic continent (Garrison 1991). These develop within microhabitats of the sea ice and are controlled by ice formation processes and physical and chemical environmental factors (Garrison 1991, Palmisano \& Garrison 1993, Ackley \& Sullivan 1994, Garrison \& Mathot
1996, Lizotte 2001). The ice-associated assemblages are characterized by large seasonal and spatial variation with respect to biomass accumulation and richness (Garrison 1991, Garrison \& Mathot 1996, Dieckmann et al. 1998). Field studies have suggested some predictability in the spatial distributions of assemblages throughout the ice-covered regions (e.g. see Garrison et al. 1986) and in the vertical distribution of differing assemblages and microhabitats throughout floes based 
on ice-formation processes and the physical and chemical characteristics of the environment (Garrison 1991, Horner et al. 1992, Ackley \& Sullivan 1994). The seasonal cycle of solar radiation and temperature, which directly controls ice formation and melting, structures the microhabitats within ice and also determines the potential for photosynthesis, growth, and survival of organisms within the ice matrix (see Garrison 1991 and Palmisano \& Garrison 1993 for a discussion). Modeling efforts - primarily using solar radiation, snow cover, ice optical properties, temperature, and related variables to predict photosynthetic potential - have been remarkably successful in reproducing the seasonal community development observed in some sea ice habitats, such as land-fast, bottom-layer communities (Arrigo et al. 1993a,b, Arrigo \& Sullivan 1994). In other habitats, such as surface layers and internal habitats, modeling efforts have suggested significant production potential (Arrigo et al. 1998). However, the predictions of models have not yet been extensively evaluated by comparisons with field observations. Moreover, the pronounced spatial variability observed in nature (e.g. Garrison \& Buck 1991) suggests that in some ice microhabitats, variables operating on much finer scales than seasonally changing solar radiation and temperature must determine biological activity. As a consequence of the uncertainty about how the physical, chemical and biological processes within sea ice control community development, studies must still rely largely on observational evidence to validate the predictions of both quantitative and conceptual models of sea ice community development (Dieckmann et al. 1998).

The present study provided an opportunity to examine some aspects of sea ice ecology during the late autumn in the Ross Sea pack ice. Based on previous studies of sea ice structure here (Jeffries \& Adolphs 1997), we expected to find a gradient from the continental shelf, where ice floes were composed predominantly of congelation ice, to the deep water regions, where ice floes were composed of frazil ice and infiltration ice (also known as snow ice). Since highly developed autumn blooms have been reported in the bottom layer of congelation ice in land-fast ice at similar latitudes to the southern Ross Sea (e.g. Hoshiai 1981, 1985, Watanabe et al. 1990), the widespread occurrence of congelation ice in the southern Ross Sea pack ice (Jeffries \& Adolphs 1997) suggested to us the potential for significant production during autumn blooms. In other Antarctic pack ice regions, frazil ice formation apparently leads to incorporation of organisms throughout floes as internal communities (Garrison et al. 1983, Garrison 1991). Such physical concentrating of biomass may also characterize the frazil ice-dominated northern outer pack ice regions of the
Ross Sea, or biomass could develop by in situ growth Similarly, accumulation of snow on ice floes in the outer pack ice region may lead to flooding at the snowice interface and the development of infiltration ice assemblages. Observations (Fritsen et al. 1994) and models for autumn ice in the Weddell Sea (Fritsen et al. 1998) indicate significant autumn production by these near-surface communities in both the late summer and autumn periods, whereas modeling for the Ross Sea (Arrigo et al. 1998) suggests little production during autumn.

Here we describe autumn ice communities in the western Ross Sea pack ice along transects between the seasonal northern ice edge and the Ross Ice Shelf. This is a first effort to relate the pattern of ice algal biomass to forcing variables such as the light and temperature regime and/or the microhabitat of the ice biota as indicated by ice structural characteristics over a large icecovered region, and this study provides the first autumn observations of sea ice communities in the Ross Sea region.

\section{MATERIALS AND METHODS}

We sampled sea ice communities primarily along 2 north-south transects (Figs. 1 \& 2) in the western Ross Sea pack ice during the austral autumn (7 May to 11 June 1998) from the icebreaker RV 'Nathaniel B. Palmer'. Continuous records of air temperature and solar radiation (Biospherical QRS-240) were collected using the ship's portable data logging system. Ice cover in the study region was estimated from selected SSM/I I (Special Sensor Microwave/Imager) satellite images obtained for the period of the study (Fig. 2). Raw SSM/I signal data received directly aboard the ship with a TeraScan System were processed into ice extent and concentration charts using the NASA Team algorithm (Comiso et al. 1997).

Ice floes $>20 \mathrm{~cm}$ thick were sampled at approximately $110 \mathrm{~km}$ intervals, i.e. every degree of latitude. Ice cores were obtained with a $7.5 \mathrm{~cm}$ diameter coring auger at a minimum of 3 locations from 'level' (unridged) portions of a $150 \mathrm{~m}$ transect. Snow depth and ice freeboard were measured at each coring location. An ice core for biological studies (i.e. measurements of chl a, particulate organic carbon and nitrogen [POC and PON, respectively], and samples to enumerate the ice biota) was measured for total length and then cut immediately into $\sim 20 \mathrm{~cm}$ sections. These were stored in $4 \mathrm{l}$ wide mouth plastic jars and placed in a freeze safe to protect against temperature fluctuations. Replicate cores were taken at the same location, no more than $0.3 \mathrm{~m}$ from the biology core, to measure temperature distributions and bulk salinity and to 
determine ice structure and stratigraphy. Temperatures were measured every $10 \mathrm{~cm}$ with a digital thermometer inserted into holes drilled into the interior of the ice core. This core was then cut into $10 \mathrm{~cm} \mathrm{sec-}$ tions that were allowed to melt before their electrical conductivity was measured and converted to salinity according to Baker (1987). Brine salinity was calculated from in situ temperature according to Assur (1958), and brine volume was calculated from ice salinity and temperature according to Cox \& Weeks (1983).

A third core was taken to study its structure and stratigraphy in the freezer aboard the ship. Thin vertical sections were made using a band saw, and the crystal texture was examined between cross-polarized filters to distinguish granular and congelation ice (Jeffries \& Adolphs 1997). Samples of the structural core were retained for stable oxygen isotope analysis to distinguish between granular frazil ice and granular infiltration ice (snow ice) layers.

Core sections retained for biological studies were melted in 1.5 to $2.0 \mathrm{l}$ of filter-sterilized seawater (pore size $0.2 \mu \mathrm{m}$ ). This procedure buffers organisms from extreme salinity and osmotic changes during melting (Garrison \& Buck 1986). These core sections were allowed to melt for $48 \mathrm{~h}$ at $-3^{\circ} \mathrm{C}$. The original volume of

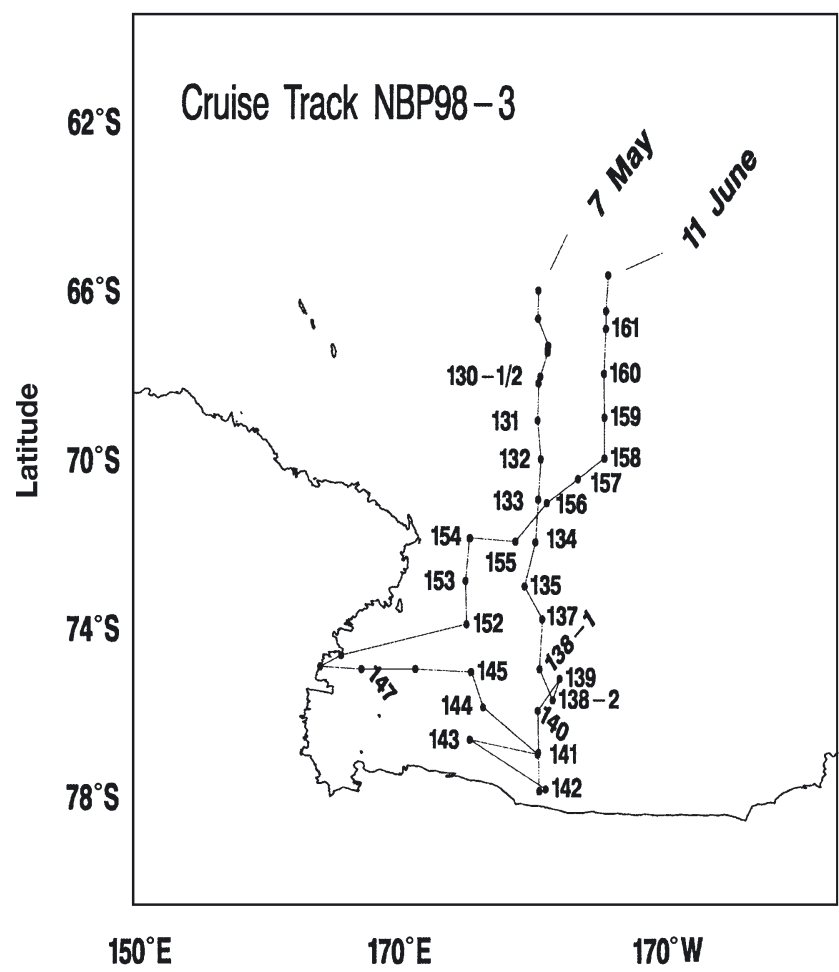

Fig. 1. Cruise track of RV 'Nathaniel B. Palmer' in the Ross Sea, 7 May to 11 June 1998 (NBP98-3). Stations where ice cores were collected for this study are identified by day of the year; multiple sites sampled on the same day are indicated with a dash and sequential numbers the ice was determined by subtracting the added seawater volume from the final melted volume; concentrations of particulate material or densities of organisms were calculated based on original ice melt-water volume. Brine samples were directly removed from the surface of ice floes by drilling 0.15 to $0.65 \mathrm{~m}$ deep holes that filled with brine flowing in from the surrounding ice. These samples were primarily taken for estimating nutrients and total $\mathrm{CO}_{2}$. These dissolved substances can be measured directly in extracted brine without the dilution effect produced by melting ice core sections. On average the brine holes were $58 \%$ of the ice thickness (32 to $82 \%$ range), so that the brine samples may reflect properties within approximately the upper half of ice floes. The brine salinity was measured directly, as described for ice core salinity.

Chlorophyll a (chl a) was determined for melted ice samples and brine. Aliquots of approximately 200 to $900 \mathrm{ml}$ were filtered through $25 \mathrm{~mm}$ Whatman glass fiber filters $(\mathrm{GF} / \mathrm{F})$ at $\leq 7$ psi, pigments were extracted in $10 \mathrm{ml}$ of $90 \%$ acetone for $\sim 24 \mathrm{~h}$ at $-20^{\circ} \mathrm{C}$, samples were allowed to warm to room temperature and were then centrifuged for $5 \mathrm{~min}$. Fluorescence of the extracted chl a was recorded before and after acidification $(10 \% \mathrm{HCl})$ using a Turner Designs fluorometer that was calibrated using a commercial purified chl a standard. Chlorophyll concentrations were calculated from the fluorescence measurements as outlined in Parsons et al. (1984).

POC and PON were measured by filtering $500 \mathrm{ml}$ aliquots of melted ice samples or brine onto precombusted $25 \mathrm{~mm}$ Whatman glass fiber filters (GF/F). Filters were folded individually in precombusted foil and stored in Petri dishes at $-20^{\circ} \mathrm{C}$ and shipped back to the laboratory for analysis. Carbon and nitrogen were analyzed using a Perkin Elmer PE2400 series II, CHN analyzer following the methods in Parsons et al. (1984).

Determinations of dissolved nutrients $\left(\mathrm{NO}_{3}+\mathrm{NO}_{2}\right.$, $\mathrm{PO}_{4}, \mathrm{SiOH}_{2}, \mathrm{NH}_{4}$ and urea) and $\mathrm{CO}_{2}$ were only done on brine samples. $\mathrm{CO}_{2}$ samples were collected first to minimize gas exchange or temperature changes when brine was exposed to the atmosphere. Samples for $\mathrm{CO}_{2}$ analysis were stored in $100 \mathrm{ml}$ glass bottles with stoppers, treated with $\sim 2 \mathrm{ml}$ of $\mathrm{HgCl}_{2}$ and sealed with silicone grease. $\mathrm{CO}_{2}$ samples were stored at $\sim 4^{\circ} \mathrm{C}$ in the dark until analysis. Samples for $\mathrm{NH}_{4}$ were collected into $50 \mathrm{ml}$ centrifuge tubes, and samples for other nutrients were collected in $60 \mathrm{ml}$ polyethylene bottles. Samples for nutrient analysis were stored at $-80^{\circ} \mathrm{C}$ and returned to the laboratory for analysis.

The analysis of total $\mathrm{CO}_{2}$ was based on acidification of seawater, followed by gas stripping and subsequent measurement of the gas stream in a nondispersive infrared analyzer (Li-Cor $\mathrm{CO}_{2} / \mathrm{H}_{2} \mathrm{O}$ analyzer, Model Li6262). Analysis of $\mathrm{NO}_{3}+\mathrm{NO}_{2}, \mathrm{PO}_{4}$ and $\mathrm{SiOH}_{2}$ was done 

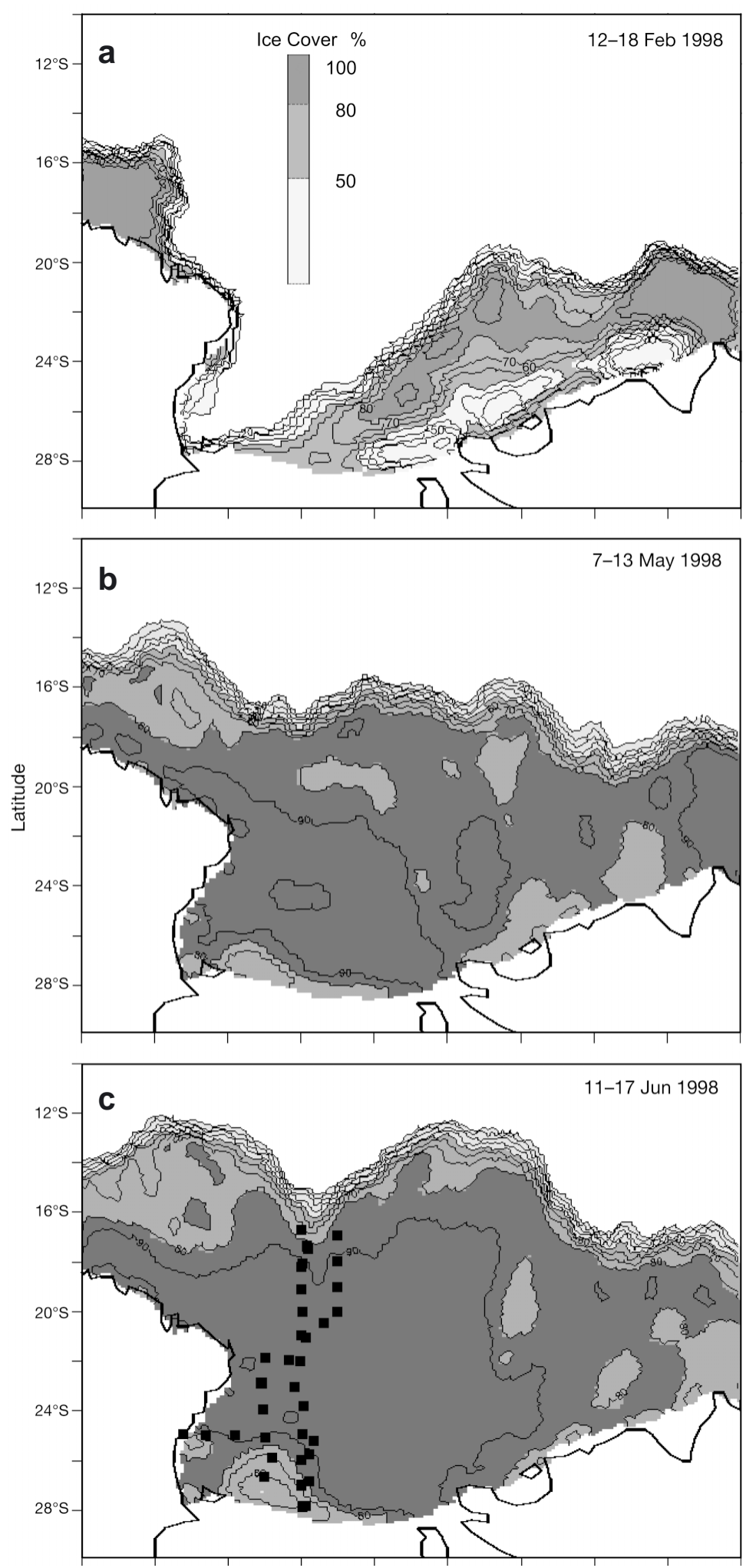

Fig. 2. Ice extent and concentration as determined from SSM/I data for (a) 12 to 18 February (approximately the summer minimum), (b) 7 to 13 May, and (c) 11 to 17 June (b and c are approximately the beginning and end of the study, respectively). Squares in (c) indicate ice floe sampling locations and thus the cruise track using standard QuickChem methods with a Lachat QuickChem 8000 instrument.

Ammonium concentrations were determined using the phenylhypochlorite method of Solorzano (1969) as adapted by W. P. Cochlan (pers. comm.). The $25 \mathrm{ml}$ brine samples were treated with $1 \mathrm{ml}$ of phenol reagent and $1 \mathrm{ml}$ of sodium nitroprusside followed by $2.5 \mathrm{ml}$ of an oxidizing solution and placed in the dark at $\sim 4^{\circ} \mathrm{C}$ for up to $3 \mathrm{~d}$ (no less than $3 \mathrm{~h}$ ) (Solorzano 1969). Samples were analyzed with a Beckman DU640 spectrometer at $640 \mathrm{~nm}$ using a $10 \mathrm{~cm}$ cell. Urea was analyzed using a diacetyl monoxime procedure adapted by W. P. Cochlan (pers. comm.) from Price \& Harrison (1987). Then, $20 \mathrm{ml}$ brine samples were acidified and treated with $2 \mathrm{ml}$ of a diacetylmonoxime solution. After water bath incubations at $85^{\circ} \mathrm{C}$ for $40 \mathrm{~min}$, followed by $30 \mathrm{~min}$ at $22^{\circ} \mathrm{C}$, the samples were read on a Beckman DU640 spectrometer at $526 \mathrm{~nm}$ using a $10 \mathrm{~cm}$ cell.

\section{RESULTS}

\section{Sea ice characteristics and environmental conditions}

The summer ice minimum in the Ross Sea occurred in approximately mid-February (Fig. 2a), about 52 d before we entered the area. By the beginning of the cruise, the northern edge of the ice reached $\sim 67^{\circ} \mathrm{S}$, with the ice cover reaching 80 to $100 \%$ concentration over most of the study area (Fig. 2b). By the end of the cruise, the ice edge had reached $\sim 64^{\circ} \mathrm{S}$, and ice concentrations had increased to $>90 \%$ (Fig. 2c). Some ice in the region survived the previous summer melt-back (see Fig. 2a), so that there was the potential for some multiyear floes among the predominantly first year ice that formed during the February to June period. However, no multi-year ice was sampled for this study.

The ice cores ranged in length from 28 to $95 \mathrm{~cm}$ (Table 1). Snow depth ranged from 0 to $36 \mathrm{~cm}$. Freeboard levels ranged from -4 to $11 \mathrm{~cm}$; the freeboard of many floes was close to sea level, so that there was a high potential for flooding at the snow-ice. There was an inverse correlation between snow depth and latitude $(\mathrm{R}=-0.55 ; \mathrm{N}=27, \mathrm{p}<0.01)$, but neither icecore length nor freeboard showed a significant association with latitude (Spearman rank correlation analysis). 
Table 1. Summary of chemical and physical parameters in sea ice

\begin{tabular}{|lrc|}
\hline Parameter & Min. & Max. \\
\hline Ice core length $(\mathrm{cm})$ & 28 & 95 \\
Snow depth $(\mathrm{cm})$ & 0 & 36 \\
Freeboard $(\mathrm{cm})$ & -4 & 11 \\
Air temperature $\left({ }^{\circ} \mathrm{C}\right)$ & -33 & 0.5 \\
Brine salinity $(\mathrm{psu})$ & 34 & 173 \\
Brine volume $(\%)$ & 3 & 21 \\
\hline
\end{tabular}

Overall, $53 \%$ of the ice was congelation ice, $34 \%$ was frazil ice, $12 \%$ was snow ice and $1 \%$ was other, miscellaneous types. However, the structural composition varied spatially (see Fig. 3), with congelation ice predominating to the south of $70^{\circ} \mathrm{S}$ (the inner pack ice) and frazil ice predominating north of $70^{\circ} \mathrm{S}$ (the outer pack ice). There was $7 \%$ infiltration ice in the inner pack ice almost $26 \%$ in the outer pack ice. Jeffries et al. (2001a) have reported that the amounts and spatial variability of these ice types in late fall 1998 were very similar to those reported in the Ross Sea pack ice in late fall 1995 (Jeffries \& Adolphs 1997). The salinity of brine sampled by flooding drill holes or calculated from ice core salinity and temperature data ranged from 34 to $173 \mathrm{psu}$ (Table 1). Ice core brine volumes ranged from 3 to $21 \%$ (Table 1 ).

Air temperatures in the study area ranged from 0.5 to $-33.0^{\circ} \mathrm{C}$ (Table 1, Fig. 4). There was a strong latitudinal temperature gradient, with temperatures generally decreasing with increasing latitude (see Fig. 4). The largest temperature decrease was noted between 70 and $72^{\circ} \mathrm{S}$, where average temperatures were -11.2 and $-19.2^{\circ} \mathrm{C}$, respectively. The lowest temperatures were recorded in the southern part of the study area, near the Ross Ice Shelf. Solar radiation also decreased with increasing latitude and as a function of date (Fig. 5). At the beginning of the study, day length was around $6 \mathrm{~h}$ at $68^{\circ} \mathrm{S}$ and $0 \mathrm{~h}$ at $76^{\circ} \mathrm{S}$. By the end of the cruise (calculations based on 1 June), the entire area was experiencing $24 \mathrm{~h}$ of darkness. A month prior to the beginning of the study ( 8 April) there would have been approximately 8 to $10 \mathrm{~h}$ of daylight over the entire area.

\section{Algal biomass, POC and PON in sea ice}

Algal biomass estimated as chl $a$, POC and PON are summarized in Table 2. All parameters showed large variability among the samples. One of the obvious features of the distributions was the markedly higher integrated chlorophyll stocks (Fig. 6) and chlorophyll concentrations (shown later) at northern stations. Sta- tistically, both chlorophyll concentrations ( $\mu \mathrm{g}$ chl a $\mathrm{l}^{-1}$ ) and integrated stocks $\left(\mathrm{mg} \mathrm{m}^{-2}\right)$ showed strong negative relationships with latitude (Spearman $\mathrm{R}=-0.69$, $\mathrm{p}>0.01$ for both analyses; $\mathrm{N}=97$ and 28 for concentrations and integrated values, respectively). Visual inspection of chlorophyll versus latitude scatter plots (not shown) suggested the area could be roughly divided into an outer $\left(<72^{\circ} \mathrm{S}\right)$ and inner $\left(>72^{\circ} \mathrm{S}\right)$ zone, with chlorophyll and integrated stocks north of $72^{\circ} \mathrm{S}$

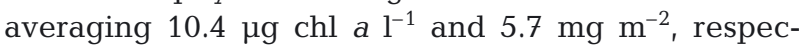
tively, and concentrations and stocks averaging $0.4 \mu \mathrm{g}$ chl a $\mathrm{l}^{-1}$ and $0.2 \mathrm{mg} \mathrm{m}^{-2}$ south of $72^{\circ} \mathrm{S}$. (Note that the designations 'outer' and 'inner' pack ice differ depending on whether the division is based on structural properties of ice or algal biomass.) Algal biomass also varied with ice structural type (see Table 2), with the maximum (>96 $\mathrm{g} \mathrm{g}^{-1}$ ) found in frazil ice in the outer ice zone (Table 2). On average, chlorophyll in frazil ice $\left(23.0 \mu \mathrm{g} \mathrm{l}^{-1}\right)$ was greater than in both infiltration ice $\left(2.9 \mu \mathrm{g} \mathrm{l}^{-1}\right)$ and congelation ice $\left(3.3 \mu \mathrm{g} \mathrm{l}^{-1}\right)$. However, with the wide range of values measured, mean values were not significantly different (Duncan multiplerange test; $\alpha=0.05)$. Chl a concentrations within ice structural types (i.e. frazil vs congelation vs infiltration

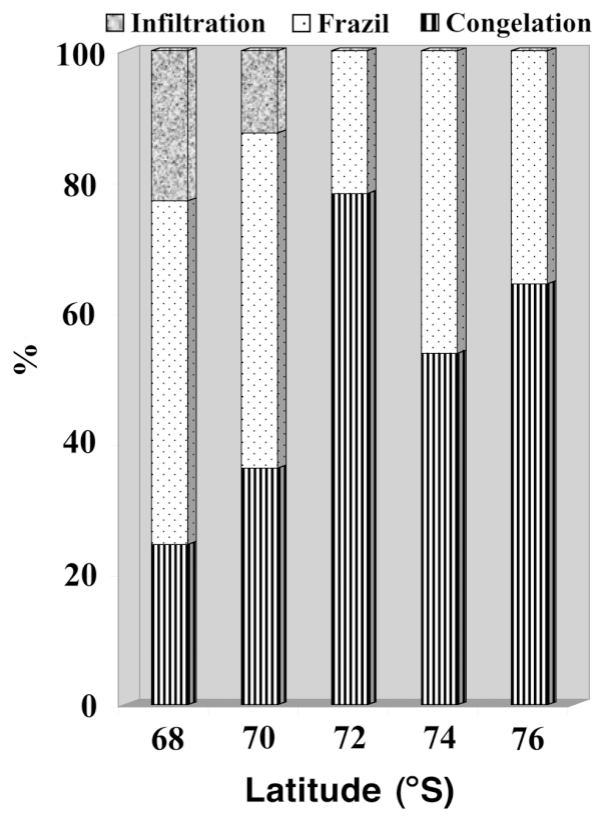

Fig. 3. Ice structural composition of cores sampled. Data grouped in $2^{\circ}$ intervals, except that data north of $68^{\circ} \mathrm{S}$ are included in that interval because the sample at $66^{\circ} \mathrm{S}$ would have been considerably smaller than the other intervals. Values are the percentages of the total core length examined. Note that we did not find infiltration ice in the southerly part of the study area in our limited core samples, but Jeffries et al. (2001a) found approximately $7 \%$ infiltration in the southern inter-ice zone 


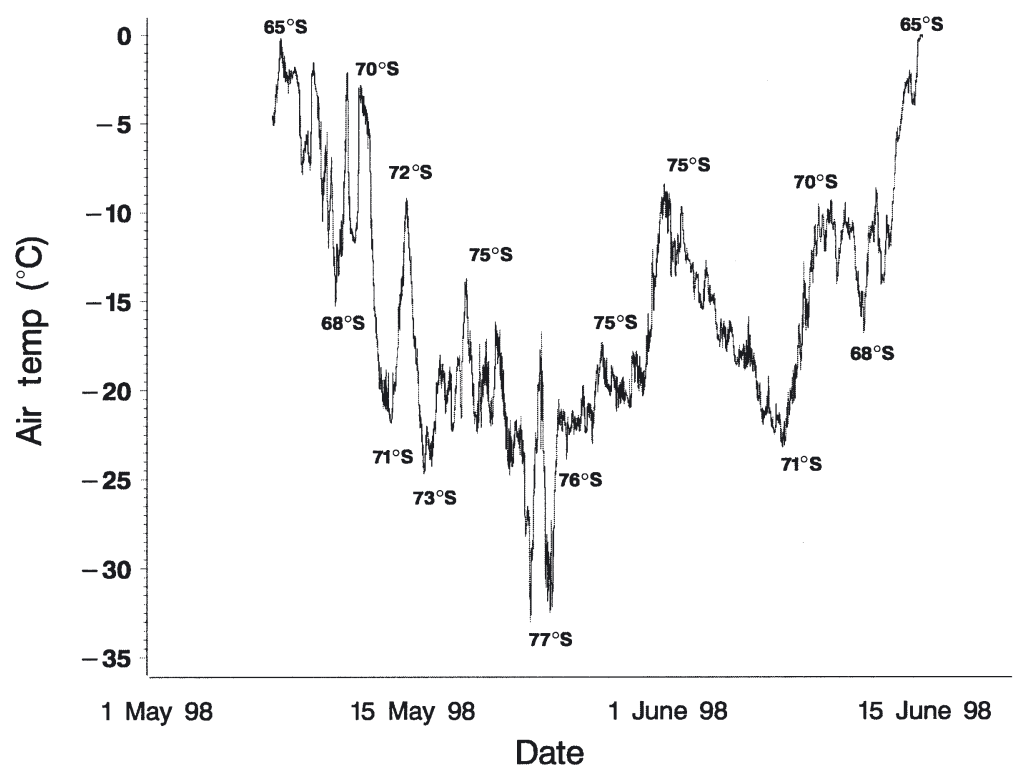

Fig. 4. Average daily air temperature $\left({ }^{\circ} \mathrm{C}\right)$ during the cruise. Latitude shown for selected days brine salinity at lower temperatures. For comparisons of relative changes in nutrient concentrations in ice versus water, concentrations normalized by salinity are also shown in Table 3. In general, the lower ratios of both nutrients and $\mathrm{CO}_{2}$ in ice versus water suggest uptake and utilization by the ice biota. Normalized nitrogen $\left(\left[\mathrm{NO}_{2}+\mathrm{NO}_{3}\right.\right.$ $\left.+\mathrm{NH}_{4}\right]$ /salinity) was negatively correlated with chl $a$, POC, and PON ( $p<0.10$ was considered significant; $N$ ranged from 18 to 22 for all comparisons calculated). Salinity-normalized $\mathrm{PO}_{4}$ and $\mathrm{SiO}_{2}$ concentrations were also inversely correlated, but with R-values that were not significant. Normalized total $\mathrm{CO}_{2}$ showed the same inverse relationships as nutrients, but R-values were only significant for POC and PON correlated with $\mathrm{CO}_{2}$.

\section{DISCUSSION}

ice), however, varied significantly in comparisons between the outer and inner ice zones: chlorophyll in frazil ice averaged 18.3 and $0.3 \mu \mathrm{g} \mathrm{l}^{-1}$ in the outer and inner ice zones, respectively, and chlorophyll in congelation ice averaged 4.5 and $0.5 \mu \mathrm{g} \mathrm{l}^{-1}$ in the outer and inner zones, respectively. Chlorophyll in infiltration ice averaged $2.9 \mathrm{\mu g} \mathrm{l}^{-1}$. In our set of samples for chlorophyll analysis, infiltration ice was only found north of $70^{\circ} \mathrm{S}$ (see Fig. 3), although infiltration ice was found in both outer and inner pack ice regions in the more extensive set of structural samples collected by the sea ice physics program (Jeffries et al. 2001a).

POC and PON were analyzed for a subset of ice samples (Table 2). POC and PON were positively correlated with chl $a$ in both frazil and congelation ice (Pearson's $\mathrm{R}=0.81$ to $0.95, \mathrm{p}<0.01$ for all comparisons). No relationship was evident for infiltration ice ( $N=4$ samples). POC and PON concentrations, however, were significantly higher in frazil ice than in congelation or infiltration ice (Duncan multiple-range test, $\alpha=0.05)$. C:N ratios were significantly higher in infiltration ice as compared to frazil ice, but no significant differences were observed between congelation and frazil ice or between infiltration and congelation ice $\mathrm{C}: \mathrm{N}$ ratios. POC:chl a ratios were not significantly different among all ice types.

\section{Nutrients and $\mathrm{CO}_{2}$}

Nutrient and $\mathrm{CO}_{2}$ concentrations in ice varied with brine salinity (Table 3 ), in part a reflection of higher

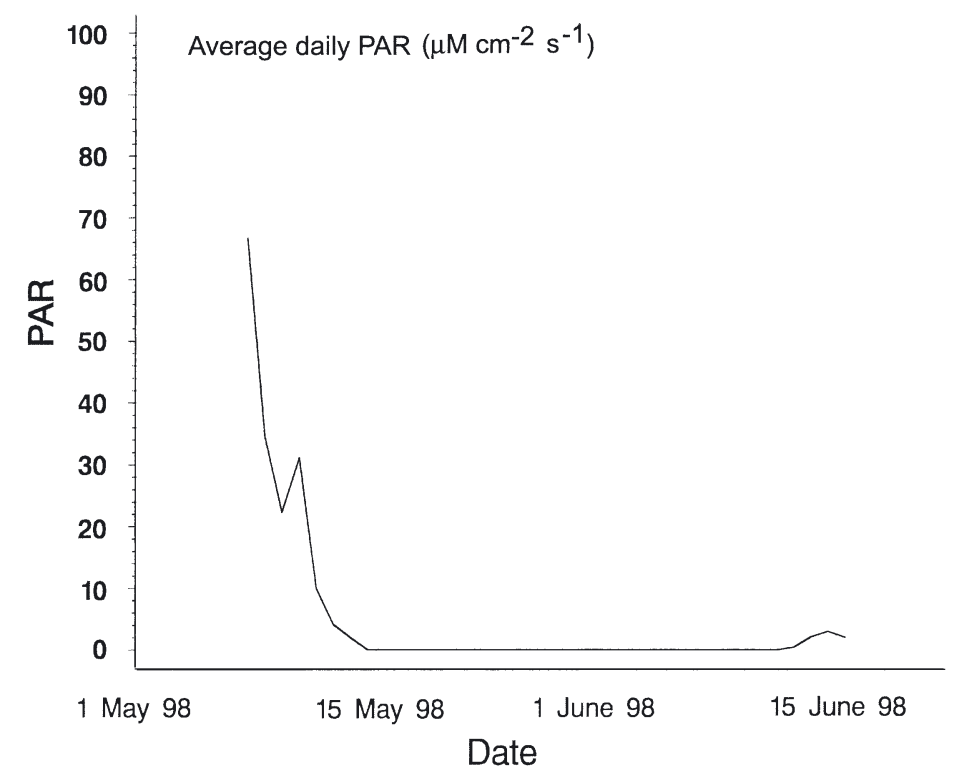

Fig. 5. Average daily (24 h) solar radiation $\left(\mathrm{PAR}_{i} \mu \mathrm{M} \mathrm{cm} \mathrm{cm}^{-2} \mathrm{~s}^{-1}\right.$ ). See Fig. 4 for latitude 
Table 2. Summary of chlorophyll a $(\mathrm{chl} a)$, particulate organic carbon and nitrogen (POC and PON, respectively) concentrations in ice floes (infiltration ice is distinguished from frazil ice [granular crystal texture] by ${ }^{18} \mathrm{O}$ compositions that indicate incorporation of snow, Jeffries et al. 2001a)

\begin{tabular}{|c|c|c|c|c|}
\hline Parameter & Median & Mean & Min. & Max. \\
\hline Chl a $\left(\mu g \mathrm{l}^{-1}\right)$ & 0.6 & 6.0 & 0.0 & 96.9 \\
\hline Integrated chl a $\left(\mathrm{mg} \mathrm{m}^{-2}\right)$ & 0.4 & 3.0 & 0.02 & 20.9 \\
\hline \multicolumn{5}{|l|}{ Chl a $\left(\mu \mathrm{g} \mathrm{l}^{-1}\right)$ by: } \\
\hline Infiltration ice & 3.2 & 2.9 & 0.43 & 5.0 \\
\hline Frazil ice & 13.5 & 23.0 & 0.0 & 96.9 \\
\hline Congelation ice & 1.0 & 3.3 & 0.0 & 14.3 \\
\hline \multicolumn{5}{|l|}{ POC $\left(\mu \mathrm{gl}^{-1}\right)$} \\
\hline Infiltration ice & 424 & 463 & 91 & 1366 \\
\hline Frazil ice & 1373 & 1611 & 307 & 4366 \\
\hline Congelation ice & 407 & 553 & 256 & 1704 \\
\hline \multicolumn{5}{|l|}{ PON $\left(\mu g l^{-1}\right)$} \\
\hline Infiltration ice & 26 & 44 & 4 & 119 \\
\hline Frazil ice & 173 & 203 & 26 & 537 \\
\hline Congelation ice & 34 & 61 & 21 & 244 \\
\hline \multicolumn{5}{|l|}{ C:N (molar ratio) } \\
\hline Infiltration ice & 13.5 & 15.0 & 6.9 & 28.2 \\
\hline Frazil ice & 9.3 & 10.0 & 6.8 & 21.0 \\
\hline Congelation ice & 12.2 & 13.7 & 7.6 & 26.0 \\
\hline \multicolumn{5}{|l|}{ C:chl a (mass ratio) } \\
\hline Infiltration ice & 289 & 551 & 132 & 1495 \\
\hline Frazil ice & 91 & 730 & 81 & 5115 \\
\hline Congelation ice & 681 & 1991 & 901 & 10319 \\
\hline
\end{tabular}

northern Weddell Sea ice edge zone. Dieckmann et al. (1998), drawing on a large compilation of data from various locations, suggest that integrated stocks of up to 10-12 $\mathrm{mg} \mathrm{chl} \mathrm{a} \mathrm{m} \mathrm{m}^{-2}$ are usual for first-year autumn pack ice. Between late summer and late autumn, a maximum

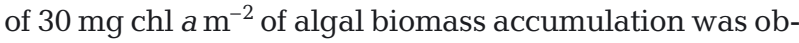
served in multi-year ice in the Weddell Sea at latitudes comparable to the present study site (Fritsen et al. 1994).

\section{Large-scale distribution patterns}

Over a large spatial scale, the seasonal and latitudinal variations in light and temperature are critical environmental variables for regulating algal growth in sea ice (e.g. Arrigo et al. 1998). On smaller spatial scales (both horizontally and vertically), ice formation dynamics and, in turn, the resulting physical and chemical properties of ice may determine where in ice floes microbial populations proliferate (Garrison 1991, Horner et al. 1992, Palmisano \& Garrison 1993, Ackley \& Sullivan 1994, Garrison \& Mathot 1996). Field studies, such as the present one, are essential in evaluating both quantitative and conceptual models of community development in sea ice.

Our finding a marked latitudinal break in biomass distributions in floes, particularly with very low stocks in floes south of $72^{\circ} \mathrm{S}$ (e.g. see Fig. 6), was initially by Palmisano \& Garrison 1993, Lizotte 2001); however, some production and biomass accumulation may also occur during the austral autumn, as indicated by model simulations (Arrigo et al. 1998, Fritsen et al. 1998) and field observations (Gleitz \& Thomas 1993, Hoshiai et al. 1996, Fritsen et al. 1994). In the Ross Sea approximately $60 \%$ of the annual increase of first year sea ice extent occurs from February (the seasonal minimum) through April (data from Arrigo et al. 1998) - a period when there is still sufficient light to support algal growth in sea ice over much of the region.

Overall, autumn sea ice algal stocks in the Ross Sea appear similar to those elsewhere in the Antarctic. Although chl a concentrations and stocks integrated throughout floes were extremely variable, they fall within ranges reported in autumn or winter first year pack ice from a number of other locations. For example, we (Garrison \& Close 1993) found integrated chlorophyll stocks ranging from very low levels to $>12 \mathrm{mg} \mathrm{chl} \mathrm{a}$ $\mathrm{m}^{-2}$ in early-winter, first-year ice floes in the

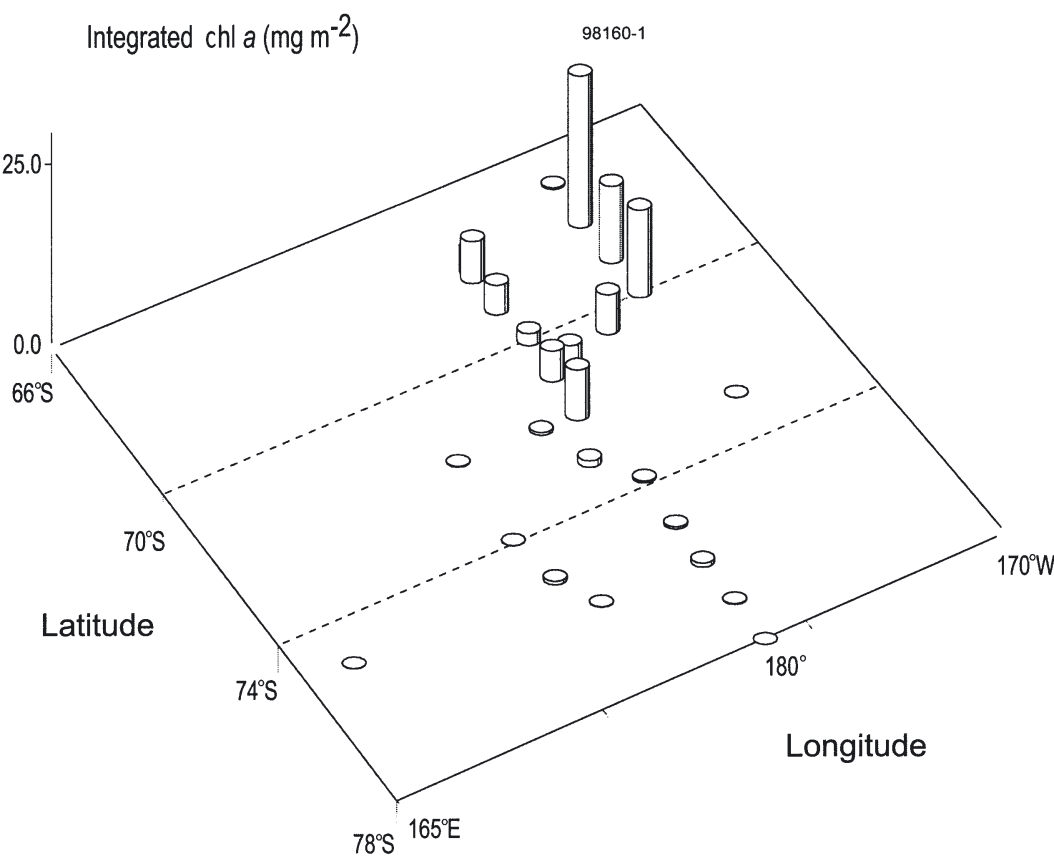

Fig. 6. Standing stocks of chlorophyll a $\left(\mathrm{mg} \mathrm{m}^{-2}\right)$ integrated over ice core length. See Fig. 1 to determine station positions. Note that these data are summarized in Table 2 
Table 3. Salinity (psu), nutrients $(\mu \mathrm{M})$, and total $\mathrm{CO}_{2}\left(\mu \mathrm{M} \mathrm{kg}^{-1}\right)$ concentrations in the water column versus ice floes. Water column nutrients and total $\mathrm{CO}_{2}$ were not measured during the present study. For a water column reference we used data collected from the upper $50 \mathrm{~m}$ at stations south of $68^{\circ} \mathrm{S}$ as part of the Joint Global Flux Studies (JGOFS) Southern Ocean Program, April to May 1997 (Process Cruise 97-3: nutrient data courtesy L. Codispoti, total $\mathrm{CO}_{2}$ data courtesy of F. Millero). As described in the 'Materials and methods' section, nutrients and $\mathrm{CO}_{2}$ are for the upper layers of ice floes only. Concentrations at bottom of table have been normalized to salinity

\begin{tabular}{|c|c|c|c|}
\hline Parameter & Mean & Min. & Max. \\
\hline \multicolumn{4}{|l|}{ Measured } \\
\hline \multicolumn{4}{|l|}{ Water column } \\
\hline Salinity (psu) & 34.415 & 34.239 & 34.512 \\
\hline $\mathrm{NO}_{3}+\mathrm{NO}_{2}+\mathrm{NH}_{4}$ & 29.57 & 28.72 & 31.88 \\
\hline $\mathrm{PO}_{4}$ & 2.02 & 1.98 & 2.21 \\
\hline $\mathrm{SIOH}_{2}$ & 71.3 & 59.5 & 78.2 \\
\hline $\mathrm{CO}_{2}$ & 2208 & 2190 & 2226 \\
\hline \multicolumn{4}{|l|}{ Sea ice } \\
\hline Salinity (psu) & 109 & 35 & 157 \\
\hline $\mathrm{NO}_{3}+\mathrm{NO}_{2}$ & 73 & 5.9 & 138 \\
\hline $\mathrm{NH}_{4}$ & 0.9 & 0 & 5.0 \\
\hline Urea & 1.6 & 0 & 11.6 \\
\hline $\mathrm{PO}_{4}$ & 4.9 & 0.1 & 8.1 \\
\hline $\mathrm{SIOH}_{2}$ & 142 & 55 & 231 \\
\hline $\mathrm{CO}_{2}$ & 6256 & 4176 & 8761 \\
\hline \multicolumn{4}{|l|}{ Salinity normalized } \\
\hline \multicolumn{4}{|l|}{ Water column } \\
\hline $\mathrm{NO}_{3}+\mathrm{NO}_{2}+\mathrm{NH}_{4}$ & 0.860 & 0.855 & 0.924 \\
\hline $\mathrm{PO}_{4}$ & 0.059 & 0.057 & 0.064 \\
\hline $\mathrm{SIOH}_{2}$ & 2.078 & 1.734 & 2.268 \\
\hline $\mathrm{CO}_{2}$ & 64.09 & 63.83 & 64.24 \\
\hline \multicolumn{4}{|l|}{ Sea ice } \\
\hline $\mathrm{NO}_{3}+\mathrm{NO}_{2}+\mathrm{NH}_{4}$ & 0.716 & 0.091 & 1.154 \\
\hline $\mathrm{PO}_{4}$ & 0.047 & 0.192 & 0.068 \\
\hline $\mathrm{SIOH}_{2}$ & 1.381 & 0.653 & 2.455 \\
\hline $\mathrm{CO}_{2}$ & 54.63 & 45.24 & 70.12 \\
\hline
\end{tabular}

puzzling. Because ice formation began in the far south in February (see Fig. 2a), floes at these higher latitudes would be expected to have had a long history of light exposure to allow growth and biomass accumulation. The likely answer to this apparent paradox lies in sea ice movement.

The drift of the 'Aurora' in 1915 to 1916 (Wordie 1921) and more recently buoys deployed on floes in 1986 to 1988 (Moritz 1988) and 1998 (Jeffries et al. 2001b, Jeffries \& Kozlenko 2002) showed that ice formed in the Ross Sea inner pack ice is rapidly advected northward. For example, buoys deployed from the RV 'Nathaniel B. Palmer' between 75 and $76^{\circ} \mathrm{S}$ and $178^{\circ} \mathrm{E}$ and $178^{\circ} \mathrm{W}$ in May 1998 moved northnorthwestward at a mean speed of $0.16 \mathrm{~m} \mathrm{~s}^{-1}(13.8 \mathrm{~km}$ $\mathrm{d}^{-1}$ ) for $107 \mathrm{~d}$ (Jeffries et al. 2001b), largely in response to the large-scale atmospheric circulation as represented by geostrophic winds (K. Morris et al. unpubl. data).
For the period March to May 1998, Arrigo et al. (2003) used satellite passive microwave data (SSM/I) to determine a mean, northward drift speed of $0.045 \mathrm{~m} \mathrm{~s}^{-1}$ $\left(3.9 \mathrm{~km} \mathrm{~d}^{-1}\right)$, with a range of $0.02 \mathrm{~m} \mathrm{~s}^{-1}\left(1.7 \mathrm{~km} \mathrm{~d}^{-1}\right)$ in March to $>0.18 \mathrm{~m} \mathrm{~s}^{-1}\left(>15.5 \mathrm{~km} \mathrm{~d}^{-1}\right)$ in May, in the Ross Sea inner pack ice. Using the mean drift speed of $0.045 \mathrm{~m} \mathrm{~s}^{-1}$, the floes that we sampled at $72^{\circ} \mathrm{S}$ on 14 May and 3 June, respectively, for example, were probably located 2.5 to $3^{\circ}$ of latitude further south in mid-February, when the ice cover began to expand after the summer minimum (Fig. 2a). Those floes were also probably older than the ice that we subsequently sampled between $72^{\circ} \mathrm{S}$ and the Ross Ice Shelf, since the more southerly ice would have formed to replace the ice being advected northward. Some of the younger, southernmost ice that we sampled must have originated in the Ross Sea Polynya that extends northward from the Ross Ice Shelf under the influence of katabatic wind surges (Bromwich et al. 1998, Arrigo et al. 2003).

The potential effect of ice advection on ice microbial communities is apparent. For example, for March to May at 75,70 and $65^{\circ} \mathrm{S}$ we calculated the sum of light hours (Fig. 7) and average temperatures (Fig. 8). The data clearly indicate a more favorable light and temperature regime for ice floes north of $70^{\circ} \mathrm{S}$, particularly during April and May. It is reasonable to suggest that the high biomass of floes in the north (see Fig. 6) is a result of a longer history of biomass accumulation under favorable growth conditions that were maintained as floes were advected northward into light and temperature regimes that continued to be favorable. In contrast, new ice forming further south to replace displaced floes would have been both younger and subjected to lower light and lower temperatures as autumn progressed.

The evidence for the age of the ice along the transect, based only on our core length data, is equivocal. Whereas snow cover increased with decreasing latitude, possibly indicating a longer history of accumulation, ice thickness based on our core samples did not. However, hourly ice observation data on floe thickness - a much larger and more representative data set-(Jeffries et al. 2001b) clearly show significant spatial variability in pack ice thickness, with a pronounced gradient from thin ice to thick ice between the ice edge and 73 to $74^{\circ} \mathrm{S}$ and from thick ice to thin ice between 73 and $74^{\circ} \mathrm{S}$ and the Ross Ice Shelf front at almost $78^{\circ} \mathrm{S}$.

In general, atmospheric temperatures decreased with increasing latitude (Figs. 4 \& 8). Low ice temperatures and the resulting high brine salinities within the surface layers of the ice could have limited growth processes (e.g. Arrigo \& Sullivan 1992), particularly in southerly occurring ice. These effects, however, should 


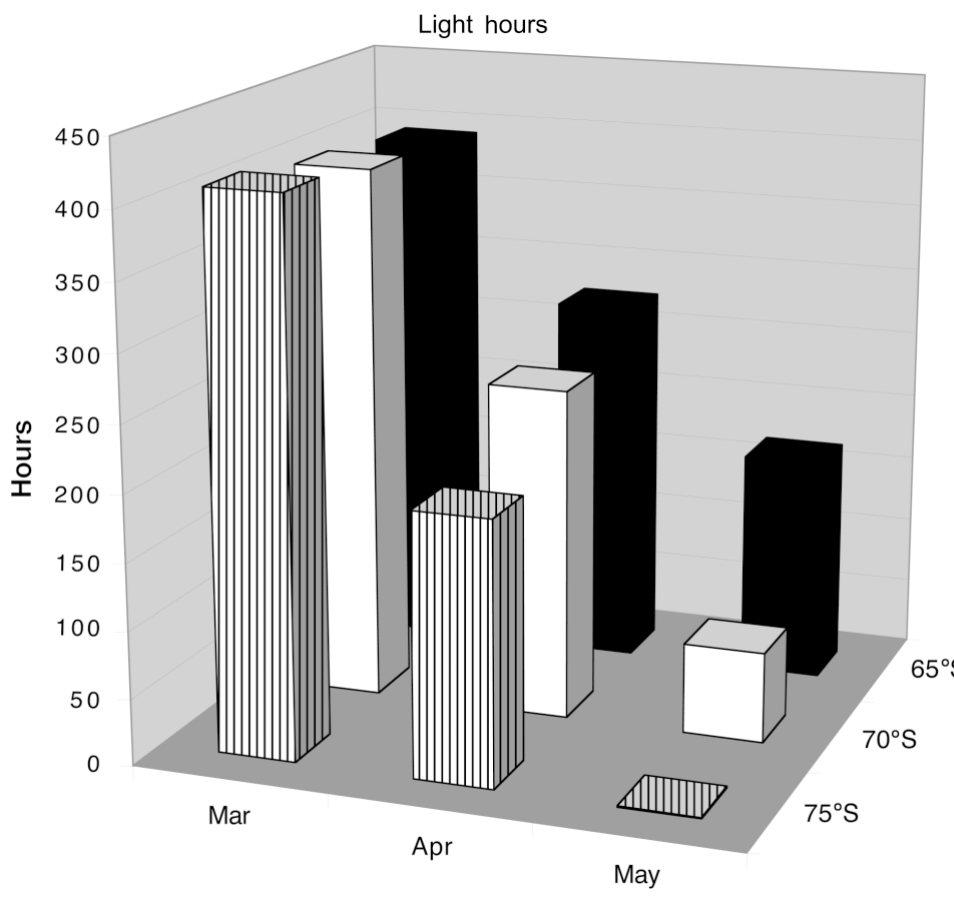

Fig. 7. Cumulative light hours calculated as a function of latitude and month ice, in situ growth seems to be more likely. First, very high concentration factors associated with algal concentrations by frazil ice are infrequent and may require concentration mechanisms such as Langmuir circulation, wave pumping, or wind drifting of surface grease ice, in addition to the mechanical trapping of cells by frazil ice crystals (see Garrison et al. 1989 for a discussion). The generally higher levels of chlorophyll associated with frazil ice through the northern study area, as well as the concentration of both frazil ice and algal populations throughout floes (see Fig. 9a), would be more consistent with in situ growth operating over a longer time- and spatial scale than the episodic harvesting events. Second, chlorophyll concentrations were also elevated in floes dominated by congelation ice (Fig. 9b,c) in the same region. Whereas mechanical incorporation can be invoked as an explanation for elevated algal biomass in frazil-dominated floes, this would not explain the elevated biomass in congelation ice. Finally, the reduction of salinity-normalized nutrient and $\mathrm{CO}_{2}$ in ice (Table 3 ) is consistent with in situ biological activity. be less apparent for bottom-layer populations that remain near the freezing temperature of seawater and experience in situ salinities similar to seawater. Thus, the latitudinal temperature gradient, by itself, does not seem to provide a satisfactory explanation for the generally low levels of algal biomass in southerly floes, and, specifically, the reason for such a sharp latitudinal break in biomass distributions could not be easily explained by air temperature. Among alternative explanations, the process of ice advection seems the most reasonable to explain the observed distributions.

Some of the biomass accumulations in outer pack ice floes (e.g. $>20 \mathrm{mg} \mathrm{chl} a \mathrm{~m}^{-2}$ and $>90 \mu \mathrm{g} \mathrm{chl} \mathrm{a} \mathrm{l}^{-1}$ ) are among the highest previously reported from first year pack ice (e.g. see Dieckmann et al. 1998). Overall the highest biomass concentrations were found in frazildominated floes (Fig. 9a), which were most common in the north of the study area (see Fig. 3). Such elevated concentrations of chlorophyll in frazil-dominated ice can result from mechanical incorporation during the frazilpancake cycle rather than in situ growth (Garrison et al. 1983, 1989). Although mechanical accumulation cannot be discounted as an explanation for some of the elevated stocks in

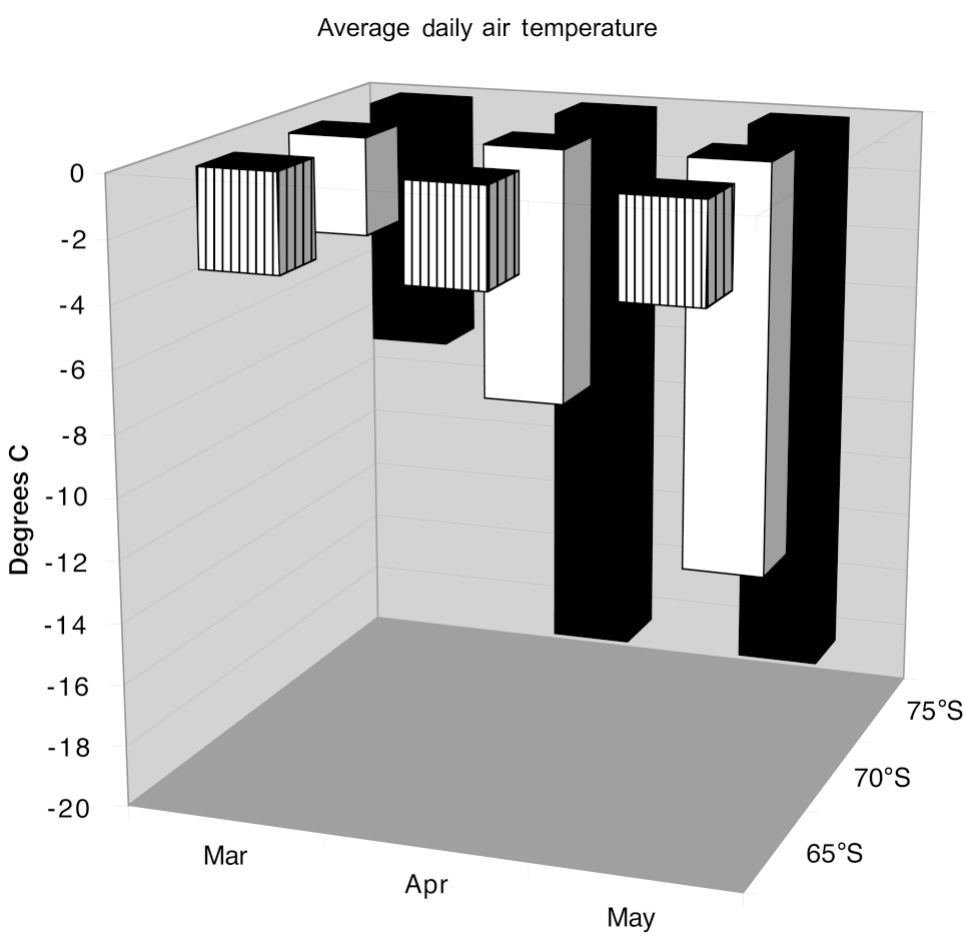

Fig. 8. Average temperature for March to May at 65, 70 and $75^{\circ} \mathrm{S}$. Data from Zwally et al. (1983) 


\section{Physical control within microhabitats in ice}

As indicated by ice structural studies (Jeffries \& Adolphs 1997), the increasing snow cover on floes in the north of the study area would provide the opportunity for development of surface-layer communities, particularly those associated with flooding and the formation of infiltration ice. Observed accumulation of algal biomass in the surface layers of ice floes, however, was low and in accordance with model predictions by Arrigo et al. (1998) (see Fig. 9). (The low accumulation in ice south of approximately $72^{\circ} \mathrm{S}$ was most probably explained by drift and the young age of ice as described above, and would not have been accounted for in the model predictions.) Low temperatures in the surface of floes, resulting in high in situ brine salinities, directly reduces photosynthetic rates (Arrigo \& Sullivan 1992), and biomass accumulation may be limited by nutrient or $\mathrm{CO}_{2}$ replenishment from the underlying water (see Fritsen et al. 1998). Low ice temperatures may also reduce nutrient exchange because of their effect on the brine volumes and the permeability of the ice (Maksym \& Jeffries 2000, Golden 2001). Brine volume values of around $5 \%$ to $7 \%$ have been suggested as practical threshold values for differentiating between permeable and impermeable ice (Arrigo et al. 1998, Fritsen et al. 1998, see discussions in Maksym \& Jeffries 2000). In the present study about $20 \%$ of ice core sections had brine volumes of $<5 \%$, and about $40 \%$ were $<7 \%$. These were largely surface or near-surface samples with mean salinity values of 126 and 87 psu (surface and subsurface, respectively) and mean temperature values of -9 and $-7^{\circ} \mathrm{C}$ (surface and subsurface). There was a strong negative correlation between brine volume and latitude $(\mathrm{R}=-0.63 ; \mathrm{p}<0.0001)$ for surface and interior samples, which was largely a result of the marked temperature gradient across the study area (Figs. 4 \& 8). We cannot differentiate whether the development of surface-layer communities was low because of the suppression of growth at low temperatures and high salinities (Arrigo et al. 1998) or whether biomass was limited by nutrient supply (e.g. Fritsen et al. 1998) or whether a combination of these effects produced the observed distributions.

Most floes with appreciable biomass showed these higher concentrations as internal populations (see Fig. 9). Internal populations are ubiquitous features of the pack ice environment and may be formed by a variety of physical and biological processes (reviewed in Garrison 1991, Palmisano \& Garrison 1993, Ackley \& Sullivan 1994, Dieckmann et al. 1998). Clearly, based on accumulated biomass, internal populations seem to be the apparent sites of significant autumn production in the Ross Sea pack ice region. With respect to internal populations associated with congelation ice (Fig. 9b,c), it would be difficult to determine whether these initially formed at the ice-seawater interface as bottom-layer populations and were subsequently incorporated in a growing ice, whether growth occurred within the ice, or a combination of both processes. a)

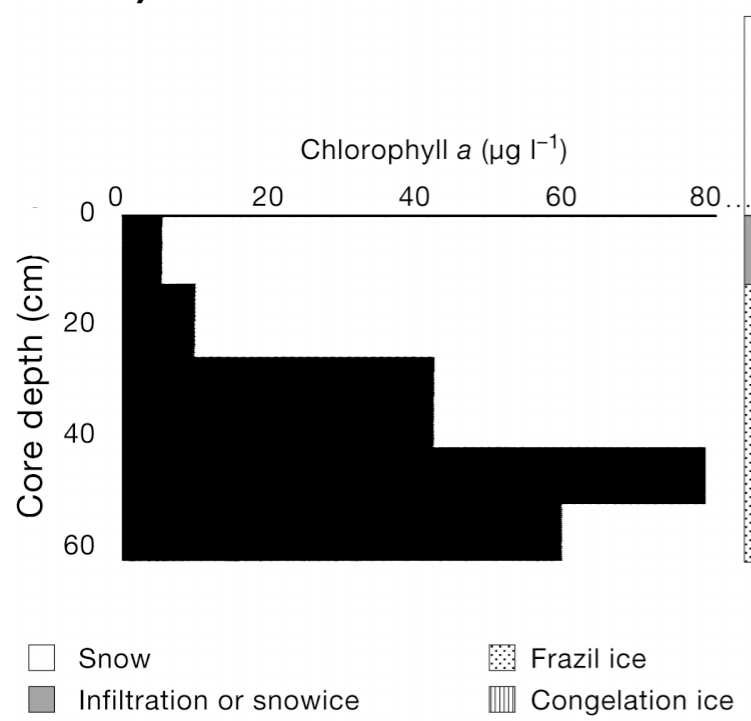

b) Ice core 157 Chlorophyll a $\left(\mu \mathrm{g} \mathrm{I}^{-1}\right)$

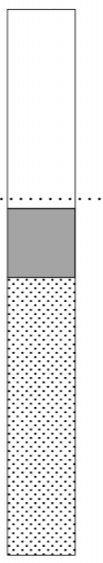

Fig. 9. Chlorophyll a distributions, snow cover and ice structure, and physical parameters in selected floes with moderate to high biomass accumulations. Total chl a contents $\left(\mathrm{mg} \mathrm{m}^{-2}\right)$ per core: (a) 20.9; (b) 4.3; (c) 5.4. See Fig. 1 for station locations 
As emphasized in the introduction, we had noted the extensive distribution of congelation ice reported by Jeffries \& Adolphs (1997), particularly in the inner ice zone, and had speculated about the potential for significant production in this ice microhabitat. Conceptual models of ice community distributions in the Antarctic have associated the productive, highly concentrated bottom-layer assemblages with congelation ice that occurs in land-fast ice regions (e.g. Garrison et al. 1986, Garrison 1991, Legendre et al. 1992, Ackley \& Sullivan 1994). Whether high biomass accumulations result primarily from ice structural makeup (i.e. the presence of congelation ice) or other aspects of the near-shore, fast-ice environment is not well known. In a previous early spring cruise (DiTullio et al. 1998), we observed and sampled rich bottom-layer assemblages in the SW Ross Sea pack ice. This prior study was too late in the season to ascertain if such communities might have been more widely distributed in the Ross Sea before seasonal opening of the Ross Sea Polynya. Were such communities to extend northward in the Ross Sea during autumn, they would need to be accounted for in ice-based production budgets for this region. Presently, estimates are based on the assumption that such communities have a markedly restricted near-shore distribution (Legendre et al. 1992) — an assumption inadequately tested from field observations.

Algal concentrations associated with congelation ice in the present study (Table 2, Fig. 9b,c), however, were considerably lower than the maximum chlorophyll concentrations of $>994 \mu \mathrm{g} \mathrm{l}^{-1}$ or integrated stocks of

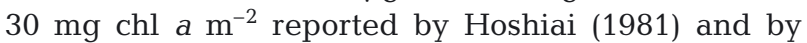
Hoshiai et al. (1996) for autumn land-fast ice (presumed to be congelation ice). The probable low light history of floes in the inner ice regions of the Ross Sea as a result of the advection and replacement by younger ice provides a sufficient explanation for the absence of bottom layers in this region. However, even in the outer ice regions, where moderate algal concentrations were found in congelation ice (Fig. 9b,c), they were more evenly distributed within floes as opposed to being markedly concentrated in the bottom few centimeters as reported from land-fast floes (Hoshiai 1981, see Garrison et al. 1986 for a discussion). Hoshiai (1981) attributed the development of highly concentrated bottom-layer assemblages to adequate light and the stability of sea ice-water interface. Ackley \& Sullivan (1994) also noted marked differences in the development of algal biomass in congelation ice in pack ice regions versus land-fast ice, and attributed them to more snow cover on pack ice and, hence, a lower light regime in pack ice bottom-layer habitats. It seems likely that the inherent instability of the bottom-layer microhabitat of pack ice floes could also limit biomass accumulation. For example, congelation ice at the bot- tom of late autumn and late winter first year floes in the Ross Sea often lacked the skeletal layer that denotes active ice growth; indeed, the smooth, scalloped bottom indicated that bottom melting was widespread (Jeffries et al. 1998, 2001a). Observations and computer simulations indicate that bottom melting is due to high oceanic heat fluxes, and that as ice is removed from the bottom the snow load is amplified and the likelihood of surface flooding and snow ice (infiltration ice) development increases (Maksym \& Jeffries 2000). Thus, a variety of factors including the pattern of ice drift in the inner ice zone resulting in ice formation and growth after the period of favorable light, the decreased light regime resulting from increasing snow depth with decreasing latitude, or periods of ablation of the bottom layer of ice floes before and after flooding, may preclude the accumulation of autumn bottomlayer assemblages in spite of extensive amounts of congelation ice in this region.

\section{Nutrient and $\mathrm{CO}_{2}$ concentrations in sea ice}

When our sampling began in May, there may have been sufficient light in the northern part of the study area to support algal growth, particularly in surface populations. We had initially intended to collect samples from only the surface layer to assess recent activity within this restricted microhabitat. Because of low temperatures and low brine volumes, it was necessary to extend cores for these collections into the upper half or more of floes to obtain an adequate sample within a reasonable time (see 'Materials and methods'). Thus these samples are an index of nutrient conditions well into the floes. Moreover, actual algal grown in these deeper layers may have occurred well before our sampling, and our measurements may not reflect conditions throughout the entire autumn growth season. That is, it seems likely that in the transition from summer to autumn in situ uptake processes may decline relative to nutrient replacement, so that April and May measurements may underestimate the nutrient draw-down during the actual growth process, which may have occurred in the February through March period. Nevertheless, nutrient and $\mathrm{CO}_{2}$ concentrations in the pack ice that we sampled should not be limiting in the sense of uptake kinetics because in situ concentrations within brine were generally higher than values in the water column (Table 3; and see Gleitz et al. 1995 for other winter reports), largely because low temperatures result in concentration of brine. These observations differ markedly from summer reports (e.g. Dieckmann et al. 1991, Gleitz et al. 1995, Günther et al. 1999, Kennedy et al. 2002), when both nutrients and $\mathrm{CO}_{2}$ can reach potentially limiting concentrations in some ice microhabitats. 
Several researchers have used salinity-normalized nutrient and/or $\mathrm{CO}_{2}$ data from ice to assess nutrient depletion within ice and/or to compare apparent nutrient depletion with biomass buildup (e.g. Garrison et al. 1990, Dieckmann et al. 1991, Fritsen et al. 1994, 1998, Günther et al. 1999, Kennedy et al. 2002). Following this same approach, we assumed a first order estimate of the total nutrient reduction in sea ice could be calculated using salinity-normalized nutrient:salinity ratios (Table 3) $\left(\mathrm{N}_{\text {relative }}=[\mathrm{N}\right.$ :salinity water $-\mathrm{N}$ :salinity ice $\left.]\right)$ and the change in salinity from approximately the time of ice formation ( 15 to $20 \mathrm{psu}$ ) minus the ice bulk salinity to calculate the total nutrient change (total $\mathrm{N}=\mathrm{N}_{\text {relative }}$ $-\Delta$ salinity). We ignored the density correction to convert the final concentration from per kilogram to per liter values and assumed a bulk salinity of $7.7 \mathrm{psu}$; the overall average for ice core samples was the same for all samples. We also set the initial ice salinity to $15 \mathrm{psu}$ to account for some brine loss in the initial stages of ice formation. Furthermore, we assumed that $\mathrm{N}$ decreases could be related to autotrophic carbon using a C:N ratio of 6.6 (Caron et al. 1990) and that C could be converted to chl a using a C:chl a ratio of 44 (A.G. \& D.L.G. unpubl. data). Similar logic was used to relate apparent total $\mathrm{CO}_{2}$ depletion to POC directly.

Similar to the findings reported by others (Fritsen et al. 1994, 1998, Günther et al. 1999, Kennedy et al. 2002), apparent nutrient draw-down accounted for only a fraction of the accumulated biomass. That is, in the present study, from calculations of apparent $\mathrm{N}$ depletion, predicted chl a was $9 \%$ of observed values, on average, but at the highest levels the observed values exceeded those predicted from apparent nutrient draw-down by $>100$-fold (data not shown). The discrepancy was larger for estimates of $\mathrm{C}$ from apparent $\mathrm{CO}_{2}$ depletion; on average, the predictions accounted for only about $2 \%$ of the observed $\mathrm{C}$ (POC), and the highest observed values exceeded those estimated from apparent $\mathrm{CO}_{2}$ utilization by $>200$-fold. Even with considerable uncertainty about the actual magnitude of nutrient draw-down in ice (discussed above), such calculations strongly point out the importance of nutrient exchange processes between ice and water to account for observed biomass accumulations.

\section{Biomass parameters and biota}

The living biota in ice communities comprise a variety of organisms ranging from bacteria to metazoans (Garrison 1991, Garrison \& Mathot 1996), and detritus is likely to accumulate within the ice matrix over time as a result of biological processes (e.g. Garrison \& Close 1993, Arrigo et al. 2003). Overall the ice samples were characterized by very high $\mathrm{C}: \mathrm{chl} a$ and $\mathrm{C}: \mathrm{N}$ ratios
(Table 2). These observations are not novel, as similarly high values have been reported in winter Weddell Sea ice (Garrison \& Close 1993) and also in early spring samples taken in the Ross Sea ice in November 1998 (Arrigo et al. 2003). As reported by Garrison \& Close (1993), POC, PON, C:chl $a$, and C:N within thicker floes increase as a function of ice thickness and agea pattern consistent with the hypothesis that detritus is accumulated in ice floes over time as the result of community processes. However, measurements of POC and PON in newly formed ice (Garrison \& Close 1993) also showed high C:chl $a$ and $\mathrm{C}: \mathrm{N}$ ratios, perhaps indicating that detritus is incorporated into newly forming ice in the same manner that algal cells are mechanically incorporated (Garrison et al. 1983).

In the present study POC and PON concentrations tracked algal stocks as indicated by chl a measurements, but, assuming reasonable C: $\mathrm{chl}$ a ratios (i.e. mean $=44$, range $=23$ to 94 , A.G. \& D.L.G. unpubl. data) for the algae in ice, only a small proportion of the total POC could be accounted for by autotrophs. Nano- and micro-heterotrophs comprised from 5 to $48 \%$ of the total biomass (determined by microscopy) over all the samples (Garrison et al. 2000), so that accounting for this additional biomass component would still not reconcile the high POC:chl a ratios (Table 2). Heterotrophic picoplankton were not examined in the study, but in previous studies (Garrison \& Close 1993) their combined biomass was similar in magnitude to that of the larger heterotrophs. Using ATP measurements and a complete inventory of the living biomass, Garrison \& Close (1993) were able to demonstrate that a large proportion of the POC in ice they examined was not part of the living biota, whereas both the high C:chl $a$ and the high C:N ratios observed in the present study would be consistent with accumulation of detritus in ice; $\mathrm{C}: \mathrm{N}$ ratios, however, need to be interpreted with some caution. For example, Günther et al. (1999) reported that under apparent nutrient stress in sea ice habitats, algal cells can produce carbon-rich but nitrogen-poor metabolites that can raise $\mathrm{C}: \mathrm{N}$ ratios to as high as 35:1 (see Table 1 for the ranges in our data). In spite of cautions about other explanations for high $\mathrm{C}: \mathrm{N}$, we believe that the excess POC is likely to be accumulated detritus. One likely candidate for this fraction is transparent exopolymer particles (TEP), which Krembs \& Engel (2001) suggested are associated with diatoms growing within sea ice. Among autotrophs, diatoms tended to dominate the high-biomass assemblages north of $72^{\circ} \mathrm{S}$, and autotrophic flagellates characterized the assemblages south of $72^{\circ} \mathrm{S}$ (Garrison et al. 2000). A more detailed manuscript on the biota is in preparation by D.L.G. et al., and further analyses of the relationship between the biota and bulk biomass parameter measurements may yield additional insights into community processes. 


\section{Conclusions}

Overall the maximum level of ice algal biomass in first-year autumn floes from the Ross Sea is similar to that reported in other Antarctic pack ice regions. Similarly, measurements of POC, PON and the composition of the biota are also consistent with other studies. Although there is a pronounced seasonal and latitudinal pattern to light availability and temperature over the summer through autumn period, the spatial development of ice communities does not correspond to these physical gradients. Rather, a pattern of winddriven sea ice advection seems to determine the environmental regime within ice floes, resulting in low development of ice community biomass in the southern part of the ice-covered regions. On a regional basis, the low community development in the south may result in lower overall ice-associated carbon fixation. However, this may be offset by increased production in floes maintained in a more favorable growth environment by northward advection.

The southern Ross Sea pack ice differs from other Antarctic pack ice regions with respect to the greater amount and geographic extent of congelation ice. In spite of an apparently suitable habitat for rich autumn bottom-layer populations, this potential was not realized. When northward drift of floes in the area is taken into account, it was apparent that no 'autumn production' occurred because the ice formed in the south well after there was sufficient solar radiation to allow algal growth. Moderate levels of biomass, however, develop in northern floes within congelation ice-dominated floes, but as diffuse internal layers. Bottom-layer assemblages in pack ice may be reduced because of lower light as a result of greater snow accumulation, or because of the dynamics of ice formation and melting at the ice-water interface. In either case, the potential for significant production by 'land-fast ice' type bottom-layer communities is not realized.

Overall biomass accumulations in the surface assemblages were low. Low ice temperatures and high ice salinities may limit growth of algal cells directly, or biomass could be limited indirectly by low temperatures reducing ice permeability and thus nutrient exchange between ice and ocean. The pattern observed in firstyear ice from the Ross Sea differs from the significant accumulation of algal biomass in surface-layer communities as reported in the Weddell Sea by Fritsen et al. (1994).

Moderate to high stocks of algal biomass develop in some autumn floes in the Ross Sea as internal populations. As with the bottom- and surface-layer communities, their development also appears to be determined by the dynamics of ice formation and drift in the southern Ross Sea.
Some caution is needed in extrapolating these conclusions to other areas of the Ross Sea Sector. First, the pattern of younger ice in the southern part of the icecovered regions may be produced by winds and ice conditions associated with the Ross Sea Polynya, and these may differ from dynamics in the ice-covered regions further to the west (see Fig. 2). Second, also west of the study location there is a considerable amount of summer ice (Fig. 2a) that will remain through the autumn and winter as multi-year floes. As reported by Fritsen et al. (1994), autumn surface-layer blooms in multi-year ice from the Weddell Sea developed considerably higher biomass concentrations than we observed in first year ice surface communities in the present study. Both of these effects, because of the specific location of our transects, could give a conservative impression of ice-based production from this region.

Nutrients and $\mathrm{CO}_{2}$ values in sea ice are reduced relative to those in surface waters. However, in situ concentrations in autumn probably remain at saturating levels for uptake kinetics because of concentration in high-salinity brine. Apparent uptake follows algal biomass, POC and PON values in ice, but quantitatively the estimated uptake will account for only a small amount of the biomass accumulation present.

Acknowledgements. This study was supported by NSF grants to D.L.G. and M.M.G. (OPP 9614201) and to M.O.J. and S. Li (OPP 9614844). We thank C. Venn and J.-L. Tison for their help with ice coring and brine collection and J. Ikävalko for assistance during the cruise. We thank the captain and crew of the 'Nathaniel B. Palmer' for their infinite help and patience, and give special thanks to J. Barnes and other Antarctic Support Associates staff members for their technical and field support. We thank W. Cochlan for helping us develop methods for the urea and ammonia measurements, and we thank G. Friederich for the analysis of the $\mathrm{CO}_{2}$ samples. Comments by 2 anonymous reviewers greatly improved the manuscript, and we thank them for their critical reviews. Interpretations and conclusions are those of the authors and do not imply the endorsement of the National Science Foundation

\section{LITERATURE CITED}

Ackley SF, Sullivan CW (1994) Physical controls on the development and characteristics of Antarctic sea ice biological communities - a review and synthesis. Deep-Sea Res 41: $1583-1604$

Arrigo KR, Sullivan CW (1992) The influence of salinity and temperature covariation on the photophysiological characteristics of Antarctic sea ice microalgae. J Phycol 28: 746-756

Arrigo KR, Sullivan CW (1994) A high resolution bio-optical model of microalgal growth - tests using sea-ice algal community time-series data. Limnol Oceanogr 39:609-631

Arrigo KR, Kremer JN, Sullivan CW (1993a) A simulated Antarctic fast ice ecosystem. J Geophys Res 98:6929-6946

Arrigo KR, Robinson DH, Sullivan CW (1993b) A high resolution study of the platelet ice ecosystem in McMurdo 
Sound, Antarctica - photosynthetic and bio-optical characteristics of a dense microalgal bloom. Mar Ecol Prog Ser 98:173-185

Arrigo K, Worthen DL, Dixon P, Lizotte MP (1998) Primary productivity of near surface communities within Antarctic pack ice. In: Lizotte MP, Arrigo KR (eds) Antarctic sea ice: biological processes, interactions and variability. Antarctic Research Series 73. American Geophysical Union, Washington, DC, p 23-43

Arrigo KR, Robinson DH, Dunbar RB, Levanter AR, Lizotte MP (2003) Physical controls of chlorophyll a, POC, and TNP distributions in the pack ice of the Ross Sea, Antarctica. J Geophys Res (in press)

Assur A (1958) Composition of sea ice and its tensile strength. In: Thurston W (ed) Arctic sea ice. National Research Council Publ. 598. National Academy of Sciences, Easton, MD, p 106-138

Baker GC (1987) Electrical conductivity, freezing temperature and salinity relationships for seawater and sodium chloride solutions for the salinity range 0 to $200 \mathrm{ppt}$. Geophysical Institute Report UAG-310. University of Alaska, Fairbanks

Bromwich D, Liu Z, Rogers AN, Van Woert ML (1998) Winter atmospheric forcing of the Ross Sea Polynya. In: Jacobs SS, Weiss R (eds) Ocean, ice and atmosphere: interactions at the Antarctic continental margin. Antarctic Research Series 75. American Geophysical Union, Washington, DC, p 101-133

Caron DA, Goldman JC, Fenchel T (1990) Protozoan respiration and metabolism. In: Capriulo GM (ed) Ecology of marine Protozoa. Oxford University Press, New York, p 307-322

Comiso JC, Cavalieri D, Parkinson C, Gloersen P (1997) Passive microwave algorithms for sea ice concentrations. Remote Sens Environ 60:357-384

Cox GFN, Weeks WF (1983) Equations for determining the gas and brine volumes in sea ice samples. J Glaciol 29: 306-316

Dieckmann GS, Lange MA, Ackley SF, Jennings JC Jr (1991) The nutrient status in sea ice of the Weddell Sea during winter: effects of sea ice texture and algae. Polar Biol 11: 449-456

Dieckmann GS, Eicken H, Haas C, Garrison DL and 7 others (1998) A compilation of data on sea ice algal standing crop from the Bellinghausen, Admundsen and Weddell Seas from 1983-1994. In: Lizotte MP, Arrigo KR (eds) Antarctic sea ice: biological processes, interactions and variability. Antarctic Research Series 73. American Geophysical Union, Washington, DC, p 85-92

DiTullio GR, Garrison DL, Mathot S (1998) Dimethylsulfoniopropionate in sea ice algae from the Ross Sea Polynya. In: Lizotte MP, Arrigo KR (eds) Antarctic sea ice: biological processes, interactions and variability. Antarctic Research Series 73. American Geophysical Union, Washington, DC, p 139-146

Fritsen CH, Lytle VI, Ackley SF, Sullivan CW (1994) Autumn bloom of Antarctic pack-ice algae. Science 266:782-784

Fritsen CH, Ackley SF, Kremer JN, Sullivan CW (1998) Floodfreeze cycles and microalgal dynamics in Antarctic pack ice. In: Lizotte MP, Arrigo KR (eds) Antarctic sea ice: biological processes, interactions and variability. Antarctic Research Series 73. American Geophysical Union, Washington, DC, p 1-21

Garrison DL (1991) Antarctic sea ice biota. Am Zool 31:17-33

Garrison DL, Buck KR (1986) Organism losses during ice melting: a serious bias in sea ice community studies. Polar Biol 6:237-239

Garrison DL, Buck KR (1991) Surface-layer sea ice assem- blages in Antarctic pack ice during the austral spring environmental conditions, primary production and community structure. Mar Ecol Prog Ser 75:161-172

Garrison DL, Close AR (1993) Winter ecology of the sea ice biota in Weddell Sea pack ice. Mar Ecol Prog Ser 96: $17-31$

Garrison DL, Mathot S (1996) Pelagic and sea ice microbial communities. In: Ross RM, Hofmann EE, Quetin LB (eds) Foundations for ecological research west of the Antarctic Peninsula. Antarctic Research Series 70. American Geophysical Union, Washington, DC, p 155-172

Garrison DL, Ackley SF, Buck KR (1983) A physical mechanism for establishing algal populations in frazil ice. Nature 306:363-365

Garrison DL, Sullivan CW, Ackely SF (1986) Sea ice microbial communities in Antarctica. BioScience 36:243-250

Garrison DL, Close AR, Reimnitz E (1989) Algae concentrated by frazil ice: evidence from laboratory experiments and field measurements. Antarct Sci 1:313-316

Garrison DL, Close AR, Gordon LI (1990) Nutrient concentrations in Antarctic pack ice during the austral winter. In: Ackley SF, Weeks WF (eds) Sea ice properties and processes. Proc WF Weeks Sea Ice Symp. Monograph 90-1, U.S. Army Cold Regions Research and Engineering Laboratory (CRREL), Hanover, NH, p 35-40

Garrison D, Gibson A, Neenan D, Coale S, Fritsen C, Jeffries M, Ikävalko J, Okolodkov Y (2000) Early stages of ice community development observed in a transect across the Ross Sea, May-June 1998. In: Abstracts Ocean Science Meeting San Antonio, Texas. American Geophysical Union/American Society of Limnology and Oceanography, Washington, DC, p 134

Gleitz M, Thomas DN (1993) Variation in phytoplankton standing stock, chemical composition and physiology during sea-ice formation in the southwestern Weddell Sea, Antarctica. J Exp Mar Biol Ecol 173:211-230

Gleitz M, Rutgers v d Loff M, Thomas D, Dieckmann GS, Millero FJ (1995) Comparison of summer and winter organic carbon, oxygen and nutrient concentrations in Antarctic sea ice brine. Mar Chem 51:81-91

Golden KM (2001) Brine percolation and the transport properties of sea ice. Ann Glaciol 33:28-36

Günther S, Gleitz M, Dieckmann G (1999) Biogeochemistry of Antarctic sea ice: a case study on platelet ice layers at Drescher Inlet, Weddell Sea. Mar Ecol Prog Ser 177:1-13

Horner R, Ackley SF, Dieckmann GS, Gulliksen B and 6 others (1992) Ecology of sea ice biota. 1. Habitat, terminology and methodology. Polar Biol 12:417-427

Hoshiai T (1981) Proliferation of ice algae in the Syowa Station area, Antarctica. Mem Natl Inst Polar Res (Jpn) E 34:1-12

Hoshiai T (1985) Autumn proliferation of ice-algae in Antarctic sea-ice. In: Siegfried WR, Condy PR, Laws RM (eds) Antarctic nutrient cycles and food webs. Springer-Verlag, Berlin, p 89-92

Hoshiai T, Tanimura A, Kudoh S (1996) The significance of autumnal sea ice biota in the ecosystem of ice-covered polar seas. Proc NIPR Symp Polar Biol 9:27-34

Jeffries MO, Adolphs U (1997) Early winter ice and snow thickness distribution, ice structure and development of the western Ross Sea pack ice between the ice edge and the Ross Ice Shelf. Antarct Sci 9:188-200

Jeffries MO, Kozlenko N (2002) Buoy deployments in the Ross Sea pack ice, 1998 and 1999-international programme for Antarctic buoys: report of the third meeting of programme participants. WCRP Informal Report No 5/2002. WMO/WCRP, Geneva, p 11-17 
Jeffries MO, Li S, Shaw RA, Krouse HR, Hurst-Cushing B (1998) Late winter first-year ice floe thickness variability, seawater flooding and snow formation in the Admundsen and Ross Seas. In: Jeffries MO (ed) Antarctic sea ice: physical processes, interactions and variability. Antarctic Research Series 74. American Geophysical Union, Washington, DC, p 69-87

Jeffries MO, Krouse HR, Hurst-Cushing B, Maksym T (2001a) Snow ice accretion and snow cover depletion on Antarctic first-year sea ice floes. Ann Glaciol 33:51-60

Jeffries MO, Morris K, Kozlenko N (2001b) Sea ice characteristics and processes in the southwestern Ross Sea. In: Berkman PA, Tipton-Everett LR (eds) Latitudinal ecosystem (LAT-ECO) responses to climate across Victoria land, Antarctica. Report of a National Science Foundation Workshop, BPRC Report No 20. Byrd Polar Research Center, Ohio State University, Columbus, p 78-89

Kennedy H, Thomas DN, Kattner G, Haas C, Dieckmann G (2002) Particulate organic matter in Antarctic sea ice: concentration and stable isotopic composition. Mar Ecol Prog Ser 238:1-13

Krembs C, Engel A (2001) Abundance and variability of microorganisms and transparent exopolymer particles across the ice-water interface of melting first-year sea ice in the Laptev Sea (Arctic). Mar Ecol Prog Ser 138:173-185

Legendre L, Ackley SF, Dieckmann GS, Gulliksen B and 6 others (1992) Ecology of sea ice biota. 2. Global significance. Polar Biol 12:429-444

Lizotte MP (2001) The contributions of sea ice algae to

Editorial responsibility: Otto Kinne (Editor),

Oldendorf/Luhe, Germany
Antarctic marine primary production. Am Zool 41:57-73

Maksym T, Jeffries MO (2000) A one-dimensional percolation model of flooding and snow ice formation on Antarctic sea ice. J Geophys Res 105:26313-26331

Moritz RE (1988) The Ross Sea data buoy project, 1986-1988. Antarct J US 23:78-80

Palmisano AC, Garrison DL (1993) Microorganisms in Antarctic sea ice. In: Friedmann EI (ed) Antarctic microbiology. Wiley-Liss, New York, p 167-218

Parson TR, Maita Y, Lalli CM (1984) A manual of chemical and biological methods for seawater analysis. Pergamon Press, Oxford

Price NM, Harrison PJ (1987) Comparison of methods for the analysis of dissolved urea in seawater. Mar Biol 9: $307-318$

Solorzano L (1969) Determination of ammonia in natural waters by the phenolhypochlorite method. Limnol Oceanogr 14 799-801

Watanabe K, Satoh H, Hoshiai T (1990) Seasonal variation in ice algal assemblages in the fast ice near Syowa Station in 1983/84. In: Kerry KR, Hempel G (eds) Antarctic ecosystems: ecological change and conservation. SpringerVerlag, Berlin, p 136-142

Wordie JM (1921) The Ross Sea drift of the Aurora in 1915-16. Geogr J 58:219-224

Zwally HJ, Comiso JC, Parkinson CL, Campbell WJ, Carsey FD, Gloersen P (1983) Antarctic sea ice, 1973-1976: satellite passive-microwave observations. NASA Special Publication 459. NASA, Washington, DC

Submitted: August 16, 2002; Accepted: May 13, 2003

Proofs received from author(s): August 25, 2003 